であり，真空パックは被曝軽減も計机，良好とのことで ある.グリッド使用の可否については被曝線童との相関 で評価が分か扎るが，乳房のようにX線被曝が問題とな る部位での検討は画質を主題に討議すべきであろう。

演題23は病室等でのX線撮影時のグリッドの使用につ いての検討を行い，準高圧撮影の必要からその適沁性を 認めた。こ机に対し昭和医大古川から $2^{\circ}$ 位の傾きで 0.2 位の濃度差を生じるので，グリッドの使用は不適当では ないかとの質問があった．時間の都合で演者からの返答 を得られず残念であったが，私の経験からやはりグリッ ドの使用は避けるべきであり，準高圧的画質を得るため にレタイプのフィルムの使用で十分その目的を達してい たので，是非追試をお䫝いしたい.

以上本年度のグリッドに関する発表のまとめを行った が，これらに関しては，まだまだ問題も多く，画質と必 要線量との相関からもその良い使用法，選択基準等につ いて諸氏のご研鑽を期待しまとめとしたい.

撮影用具（演題番号 $57 \sim 60$ )

中野 努（産業医科大学病院放射線部）

このセクションは注腸検査のための補助具の発表が 3 題, 胸腹部用フィルムチェンジャの補助具に関する発表 が 1 題あった。演題57は空気加圧により注入を行う注腸 器に自作の安全装置を装着し, 高圧注入の事故を防止し ようとするものである。ただ，この発表の価值は安全装 置の考案という点にあると思うので，考案の過程で検討 した事項についての詳細を説明する必要はないと思う。 安全装置の概要，作動原理，セールスポイントを主体に 発表されたほうが有意義でなかったかと思う。

質問 （佐々木）安全装置のコストは？

答 安全弁 1 個は 100 円くらいで，かつ反復使用でき る.

演題58は注腸撮影用の補償フィルタに関する発表であ る.この発表での新しい点は，透視像を見ながら遠隔で フィルタの位置を調整できる点にある。

質問（松戸市立病院 高梨）実際の被写範阘は TV モニタ画面より大きいので，フィル夕位置がモニタから 外れる場合は補償の程度が分からないのではないのか？

答 フィルタはたいてい中心近くまで入る。また，フ ィルタのコントローラのつまみの位置でフィル夕の位置 が分かる。

質問 （座長）フィル夕の形状を CT の A-P 方向の 厚さから決めているが, 実際の撮影では A-P 以外の方向 もあるので, 現在のフィル夕の形状がベストではないの
ではないか？

答 確かに現在のフィルタでは強い斜位の場合, 補償 できない。このため，現在あるフィルタを固定式にして， さらにもう一つ電動のフィルタを取り付ける予定である。 演題59も注腸撮影用補償フィルタについてのものであ るが，こちらはフィル夕の効果に関する発表である。フ イルタ使用による効果は, 濃度補償だけでなく, ハレー ションX線を押さえて，ホトタイマを安定して作動させ る効果と中心部での散乱線含有率を減少させる効果があ ることを報告した，発表の中でフィルタのある場合とな い場合の違いを，X線量, 撮影時間のような定量的な值 で表現していたことを評価したい.

演題60は胸腹部撮影用フィルムチェンジャの患者保持 具に関する発表である。握りの部分が 3 段になったハン ドグリップによって，胸腹部側面撮影での患者の体位保 持を行うものである。ほぼ同じ保持具について，42回総 会で谷口らが発表を行っている，同様な器具の発表を行 う場合，すでに発表されたものとの違いを明確にする必 要があると思う。

\section{RI-1 骨塩定量他（演題番号155～160）}

\section{増田一孝（滋賀医科大学病院）}

RI-1における発表は, 骨塩定量 $=4$ 題, その他 2 題で ある，骨塩定量検査について現状ではマサチューセッツ HP の R. Neer 博士らの主張する「技術的要因で $2 \%$ 以 上の変化があるのに治療の変化が年 $2 \%$ 程度しかないの では無意味」とする意見と，装置メーカ社長のR.B. Mazess 博士らの主張する「海綿骨では年 5 ～15\%の変 化があるので有用である。」とい意見に 2 分される。し 加し米国公衆衛生医療技術部門 (OHTA) は1987年連邦 政府に対して“保険の払い戻しを行わないこと”を勧告 した経過があり，各演題の発表者が精度管理にどのよう な工夫と検討がなされているかに特に注目した。

演題155 愛仁会高梘病院・川勝らの発表は，DPA 測 定を用いての検討を主に行っている。この発表の中で注 目す心゙きことは，ファントムスタディーでの再現性は， 10 回測定で $\mathrm{SD}=0.004, \mathrm{CV}=0.423 \%$ ，ということにあ るが，人体に適用する際の障害因子として，脂肪・腸内 ガス・年歯令な゙が精度低下させる因子として考えられる。 この点をどう補正するか，また腰椎における值にしても， 測定部位により測定值は当然異なるが，この点をどのよ

うに解決するかが今後の課題であろう.

演題156 新潟大学病院・大滝らの発表は, SPA 法の $\mathrm{CV}$ 值は1.2〜1.7\%，DPA 法を用いた腰椎測定での CV 